\title{
ІДЕЇ Т. Д. ДЕМ'ЯНЮК ЩОДО ВИКОРИСТАННЯ ПЕДАГОГІКИ НАРОДОЗНАВСТВА У НАЦІОНАЛЬНО-ПАТРІОТИЧНОМУ ВИХОВАННІ МОЛОДШИХ ШКОЛЯРІВ
}

\author{
Ірина Поліщук \\ Украйна, м. Рівне, Рівненський державний гуманітарний університет; \\ Аспірант кафедри теорії і методики виховання
}

DOI: https://doi.org/10.31435/rsglobal_wos/31032020/7010

\section{ARTICLE INFO}

Received: 20 January 2020

Accepted: 13 March 2020

Published: 31 March 2020

\section{KEYWORDS}

T. D. Demianiuk, pedagogy of ethnography, Ukrainian folk pedagogy, folk traditions, national-patriotic education, junior schoolchildren.

\begin{abstract}
The article is devoted to the analysis of the creative inheritance of T. D. Demianiuk on the use of ethnography in the national-patriotic education of junior students. Her main works are characterized in the article, among them: "Education of the spirituality of students of the comprehensive school by means of ethnography"; "The use of folk pedagogical deontology in the creation of a national education system"; "Calendar-ritual holidays at school: Part 1. Winter cycle"; "Calendarritual holidays at school: Part 2. Spring cycle"; "The revival of folk traditions. Part 3. Summer cycle of calendar and ritual holidays"; "Celebration of calendar and ritual holidays in modern school. Part 4. Autumn cycle"; "The content and methodology of ethnographic work in modern school: ethnographic work in extracurricular activity" and others Based on the analysis of the pedagogical ideas of T. D. Demianiuk and the analysis of the educational system of elementary school teachers in Rivne region, organized according to her ideas, the basic means of pedagogy of ethnography are distinguished and characterized. All of them can help to bring up a decent citizen of the country and prepare future teachers to use effectively of pedagogy of ethnology in the national-patriotic education of junior students.
\end{abstract}

Citation: Ірина Поліщук. (2020) Idei T. D. Demianiuk Shchodo Vykorystannia Pedahohiky Narodoznavstva u Natsionalno-Patriotychnomu Vykhovanni Molodshykh Shkoliariv. International Academy Journal Web of Scholar. 3(45). doi: 10.31435/rsglobal_wos/31032020/7010

Copyright: (C) 2020 Ірина Поліщук. This is an open-access article distributed under the terms of the Creative Commons Attribution License (CC BY). The use, distribution or reproduction in other forums is permitted, provided the original author(s) or licensor are credited and that the original publication in this journal is cited, in accordance with accepted academic practice. No use, distribution or reproduction is permitted which does not comply with these terms.

Постановка проблеми, їі зв'язок 3 важливими проблемами. Сучасний період розвитку суспільства в незалежній Україні відкриває широкі можливості для оновлення змісту освіти на основі народності школи, що дає змогу формувати духовно багате покоління людей. Це обумовлює новий підхід до виховання дітей та учнівської молоді. На сьогодні виникла соціальна потреба у формуванні творчої особистості, яка змогла б розв'язувати як щоденні, так i масштабні завдання, що забезпечують не просто виживання, а стійкий прогрес нації. Виховання такої особистості вимагає, перш за все, удосконалення національно-патріотичного виховання, врахування особливостей розвитку суверенної України, іiї потреб у відродженні нації, використання традиційного вміння і бажання українського народу працювати на благо процвітання своєї держави.

Використання педагогіки народознавства $\epsilon$ ефективним засобом національнопатріотичного виховання молодших школярів, адже під впливом системи народознавчих заходів діти проходять шлях розвитку від підсвідомого розуміння своєї етнічної належності в молодшому віці до національної зрілості, до усвідомлення себе патріотом власної країни. 
Сучасна українська вчена, педагог, фундаторка експериментально-виховної діяльності в незалежній Україні Тамара Дмитрівна Дем'янюк (1944-2013) вважала, що «ефективність формування творчої особистості, безперечно, підвищується, якщо забезпечуються: використання педагогіки народознавства; засвоєння учнями знань про країну, народ, його культуру і спосіб життя, вмінь і навичок у їх практичному застосуванні; співробітництво вчителів та учнів у розробці різних форм і видів діяльності; організація активно-творчої патріотичної діяльності учнів у позаурочний час» [14].

Аналіз останніх досліджень і публікацій. Дослідження форм, методів і засобів національно-патріотичного виховання свого часу здійснили І. Бех, Т. Гавлітіна, П. Ігнатенко, В. Кіндрат, О. Сухомлинська, К. Чорна та ін. $[1,16,19]$.

Теорію i практику виховання школярів на ідеях народності обгрунтовували О. Духнович, В. Кузь, О. Любар, Ю. Руденко, М. Стельмахович, В. Сухомлинський, К. Ушинський, Д. Федоренко та ін. [15, 17, 18].

Однак цілі десятиліття ігнорування педагогіки народознавства, заідеологізованість освіти й педагогіки в цілому зумовлюють й актуалізують потребу вивчення місця та ролі української народної педагогіки в сучасному вихованні підростаючого покоління, зокрема, на часі вважаємо вивчення можливостей використання педагогіки народознавства в національнопатріотичному вихованні молодших школярів. Водночас не менш актуальним вважаємо вивчення поглядів сучасних педагогів на означену проблему.

Мета статті полягає у здійсненні цілісного аналізу ідей Т. Д. Дем'янюк щодо використання педагогіки народознавства у національно-патріотичному вихованні молодших школярів.

Виклад основного матеріалу. На сьогодні безсумнівним твердженням $€$ те, що успішному здійсненню національно-патріотичного виховання сприяють засоби педагогіки народознавства, як-то: рідна мова, історія народу, краєзнавство, родовід, природа рідного краю, народна міфологія, фольклор, національне мистецтво, народний календар, національна символіка; народні прикмети, вірування, релігійні виховні традиції, родинно-побутова культура, національні традиції, звичаї, обряди та ін.

Процес формування особистості молодшого школяра засобами народознавства, на думку Т. Д. Дем'янюк, включає в себе взаємопов'язану діяльність вчителів і учнів з розвитку моральних почуттів і рис поведінки, а саме: любов до Батьківщини, відданість їй; активну працю на благо народу; примноження трудових традицій, звичаїв народу; бережне ставлення до історичних пам'яток, традицій, звичаїв рідної України, прагнення до зміцнення честі та гідності своєї держави; прив'язаність і любов до рідного краю; хоробрість, мужність, готовність захищати Батьківщину. Справжня людина успішно формується в активній практичній діяльності, яка поліпшує умови життя в рідній місцевості, підвищує матеріальний та духовний рівень народу. Провідне значення має активність школяра, його бажання вдосконалювати себе, прагнення до зберігання і розвитку традиції рідного народу; єдність слова і діла, поглядів i вчинків, моралі і поведінки $[2,4,5,6,12,13]$.

У перші роки незалежності України Т. Д. Дем’янюк стала першою, хто почав системно і методично заповнювати прогалину використання педагогіки народознавства у новій національній системі виховання. Вже починаючи з 1992 р., вченою було укладено й видруковано низку посібників, які стали основою в діяльності педагогів молодої суверенної країни, як-то: «Виховання духовності учнів загальноосвітньої школи засобами народознавства» (1992); «Використання народної педагогічної деонтології у створенні національної системи виховання» (1996); «Календарно-обрядові свята в школі: Ч. 1. Зимовий цикл» (1996); «Календарно-обрядові свята в школі: Ч. 2. Весняний цикл» (1996); «Відроджуємо народні традиції. Ч. 3. Літній цикл календарно-обрядових свят» (1996); «Відзначення календарнообрядових свят в сучасній школі. Ч. 4. Осінній цикл» (1996); «Зміст та методика народознавчої роботи в сучасній школі: народознавча робота в позаурочний час» $(1996)[2,4,5,6,9,12,13]$.

У зазначених навчально-методичних посібниках Т. Д. Дем'янюк виклала основні ідеї і навела приклади використання педагогіки народознавства у національно-патріотичному вихованні учнів. Так, Тамара Дмитрівна виділяла у цьому процесі понятійний і діяльнісний аспекти, що дає змогу залучити всіх учнів початкових класів до освітньо-виховного процесу. Показовим для такої діяльності є активне використання народної математики, метеорології, медицини, хліборобської 
справи та інших сфер народних знань і вмінь. Найголовніше тут $\epsilon$ те, що учнів самостійно здійснюють пошуково-дослідницьку роботу - забезпечують збір матеріалів.

Інтенсифікація освітньо-виховного процесу здійснюється за допомогою дидактичних і проблемно-дискусійних, методів стимулювання і заохочення пошукової діяльності учнів, що сприяе цілеспрямованому розвитку їхніх пізнавальних інтересів, суспільно-гуманістичній активності і самостійності, появі позитивних мотивів оволодіння знаннями народознавчого характеру.

Т. Д. Дем’янюк підкреслювала, що активно-творчої народознавчої діяльності школярів учителі домагаються, поєднуючи пояснювально-ілюстративні та репродуктивні методи 3 творчими іграми, індивідуальними завданнями і широким залученням батьків, членів родини.

У своїй роботі вчителі початкових класів Рівненщини упродовж тривалого часу використовували й використовують дотепер програму 3 народознавства, розроблену співробітниками Науково-дослідної лабораторії під керівництвом Т. Д. Дем'янюк [9]. У цій програмі виокремлюється змістове наповнення: етнічна історія українців; виникнення і формування народу, нації та етнічні ознаки, елементи традиційно-побутової культури; позитивні народні звичаї, традиції, культурні цінності, народне мистецтво; розвиток національних традицій у сучасній культурно-побутовій сфері; етнічні процеси взаємодії, взаємовпливу в традиційно-побутовій сфері буття українців та інших народів, що живуть на території України.

Для активізації інтелектуальної діяльності молодших школярів вводяться різні за складністю пізнавальних завдань питання, елементи діалогу, дискусії, зіставлення різних поглядів, фрагменти змагань, турніри-вікторини. На них учні молодшого шкільного віку співають українські пісні, виконують народні танці, читають вірші, влаштовують народні ігри [9].

Отже, підготовка і проведення заходів народознавчого характеру вимагають від молодших школярів пошуково-краєзнавчої діяльності, під час якої вони вивчають пісенний і словесний фольклор, дитячі ігри, іграшки, розваги, а також зразки хореографічної, декоративно-прикладної, трудової, суспільно-гуманістичної діяльності. Ефективною і цікавою формою роботи з молодшими школярами $\epsilon$ клуби «Джерельце», «Чомучки», «Краєзнавство», «Вітчизнознавство» (Костопільський район), покликані формувати вміння та навички активно-творчої діяльності народознавчого характеру. Тут учні живуть народною мудрістю, діяльність вкарбовується у слові, слово стає діяльністю. Основними напрямами діяльності цих клубів є: ознайомлення з минулим i теперішнім життям українського народу; миротворча і природоохоронна діяльність; збереження і примноження звичаїв, обрядів, традицій свого народу; активно-творча, національно-патріотична діяльність; вивчення, засвоєння та пропаганда народної творчості, літературної спадщини поетів, письменників краю, країни; доброчинна діяльність.

Як показує практика діяльності педагогів Городищенської ЗОШ I-III ст. Березнівського району, важливою умовою в організації народознавчої роботи $\epsilon$ створення навчальноматеріальної бази, тобто виховних осередків, які об'єднані в народознавчий центр Шевченківська світлиця. Керівництво таким центром здійснюють учні. У його склад входять: історико-краєзнавчі, літературно-етнографічні, кімнати народознавства, «Берегиня», Пам’яті, Рідного краю, «Бабусина казка», народного побуту; зали: Козацької слави, Національної символіки, Історії української діаспори; народознавчі осередки з музейними експонатами, бібліотека тощо.

Значну увагу в школах Рівненщини, творчо реалізовуючи ідеї Т. Д. Дем’янюк, приділяють організації Шевченківських світлиць, які на сьогодні $є$ одним із найважливіших осередків національного і духовного відродження, справою не тільки вчителів, а й всієї громади.

Приміром, Шевченківську світлицю ліцею м. Корця, прикрашають вишиті учнями, в тому числі молодшого шкільного віку, портрет Т. Шевченка і його «Заповіт», українські рушники; портрети гетьманів України; різьблення за творами українських поетів минулого i сучасності; старовинна скриня, столи, судники; старовинний та сучасний український посуд; старовинні речі домашнього вжитку: полотно, одяг, взуття, знаряддя праці. Увесь матеріал про Т. Шевченка класифіковано за такими рубриками: «Народився, щоб осяяти світ», «Подорож на Волинь і Поділля», «Істинно народний поет», «Він був і $є$ великим художником», «Ми тебе не забули, Тарасе...». Для цього ліцею характерна своя система народознавчої роботи. У всіх початкових класах діють гуртки «Народознавство», «Рідний край», на яких вивчають теми: «Фольклор - душа народу», «Природа нашого району», «Села Кореччини» [3]. 
Наприклад, при музеї «Берегиня» Білокриницької ЗОШ Рівненського району діють групи (пошукова та екскурсоводів), члени яких добирають матеріал і проводять тематичні екскурсії: «Хата моя, біла хата», «Витвори мистецтва», «Український народ», «А мати вишивала рушники».

Досліджуючи процес формування особистості засобами народознавства в Березнівському, Острозькому, Здолбунівському районах та в м. Рівне, Т. Д. Дем'янюк проаналізувала національно-патріотичну діяльність школярів, їх прагнення до нагромадження знань, тобто пошуково-пізнавальну діяльність народознавчого характеру. На основі аналізу досвіду робити вчителів початкових класів Городищенської, Бистрицької, Білашівської, Полянської, Прислуцької ЗОШ І-ІІІ ст. Березнівського району, Могилянської ЗОШ І-III ст. № 1, 3 Острозького району, ліцею м. Корець, Білокриницької ЗОШ I-III ст. Рівненського району, ЗОШ № 4, 22, 24, 26 м. Рівне та багатьох інших, вчена обгрунтувала застосовування традиційних та інноваційних видів пізнавальної діяльності школярів народознавчого характеру: заняття в гуртках та факультативах народознавства, участь у роботі клубів, творчих об'єднань, товариств, центрів, тематичних масових, групових та індивідуальних формах та видах діяльності. Згідно 3 такими підходом суспільно-гуманістичну діяльність школярів вона визначала як специфічну форму ставлення їх до суспільного життя, спрямованого на активну участь у ньому. У неї входять: а) інформаційна робота школярів у колективі ровесників і за місцем проживання: огляди подій суспільного життя села, міста за матеріалами газет, журналів, радіо- і телепередач, історичні розповіді-естафети, народні казки-вистави, родинні свята та ін.; б) виконання творчих доручень народознавчого характеру; в) пошуково-дослідна, краєзнавча та героїко-патріотична робота: участь в експедиційно-пошукових групах, екскурсіях, туристичних походах, зустрічах із старожилами своєї місцевості; створення книги «Історії села»; збір легенд, пісень, дум, переказів, казок, дум, щедрівок, колядок; особиста участь у роботі гуртів кобзарського, сопілкарського мистецтва, етнографічних груп та фольклорних ансамблів; підготовка виступів, текстів екскурсій за матеріалами музеїв «Історія села», кімнат народознавства, Шевченківських світлиць тощо.

Одним з ефективних засобів педагогіки народознавства $є$ гра, спрямована на практичне пізнання навколишнього світу через відтворення дій та взаємин дорослих. «Гра понижує втомленість, сприяє більш легкому встановленню контактів з оточуючими. Відомо, що наш народ дуже високо цінував міцне здоров'я, силу і витривалість, стійкість і спритність, відвагу і рішучість, наполегливість і дисциплінованість», - зауважувала Тамара Дмитрівна Дем'янюк [6]. Здійснений нею аналіз національно-патріотичного виховання учнів початкових шкіл Рівненщини дав змогу зробити висновок, що педагогами ігри народознавчого характеру проводилися і пізнавальні, і сюжетно-рольові, й творчі. «Безперечно, гра не народжується 3 нічого. Діти грають в те, що бачили, про що чули, читали, що вразило. Необхідна умова гри вдало підібрана роль. Гра не може виникнути за примусом і може дати ефективні результати», - переконувала вчена [5, 12].

У початковій школі відкриваються великі можливості трудової діяльності учнів молодшого шкільного віку, як-то: виконання робіт на пришкільній ділянці, самообслуговування, чергування, озеленення території, охорона оточуючого середовища, посадка і догляд за кімнатними рослинами, робота «голубих патрулів», збір лікарських рослин, робота на полях, городах, у шкільних кооперативах тощо.

Зрозуміло, що формування національно-патріотичної особистості неминуче передбачає створення системи роботи, в якій забезпечувалася б передбачена єдність урочної та позаурочної діяльності. Розроблена Т. Д. Дем'янюк система сприяє підвищенню ефективності цілісного педагогічного процесу в закладі освіти. «Формування особистості засобами народознавства 3 професійно-трудовим спрямуванням - складний і багатогранний процес, він вимагає високої організації педагогічної праці та активно-творчої діяльності учнів, чіткості та цілеспрямованості в роботі, вміння зосередитися на головному», - вважала Т. Д. Дем'янюк, характеризуючи технології національно-патріотичного виховання [14].

За ідеями Т.Д.Дем'янюк, організовуючи народознавчу діяльність учнів молодшого шкільного віку, педагоги підтримують ініціативу, творчість, самостійність, сприяють створенню учнівських об'єднань, які будують свою роботу на принципах природовідповідності, культуровідповідності, спадковості, історизму, народності, систематичності, послідовності та ін. 
При цьому, на переконання вченої, «розвиток і вдосконалення народознавчої роботи в школі потребує дійового науково-методичного забезпечення, суть якого полягає в цілеспрямованій роботі надання допомоги вчителям у підвищенні ефективності формування особистості засобами народознавства, побудові такого виховного процесу, який би сприяв активно-творчій науковопатріотичній діяльності учнів» [4].

Аналіз досвіду роботи методичних кабінетів, здійснений Т. Д. Дем'янюк в презентований у іiі науково-педагогічних працях, свідчить, що основними напрямами діяльності цих кабінетів у формуванні громадянина-патріота суверенної України є: аналіз ефективності роботи педагогічних колективів 3 національно-патріотичного виховання школярів; визначення рівня науково-теоретичної і методичної підготовки педагогічних кадрів $[3,7,8,10,11]$.

Зокрема, у відповідності з оновленим змістом виховання та стратегічними завданнями, які стоять перед органами освіти, - створення і утвердження національної системи виховання в навчальні плани всіх форм підготовки педагогів вносяться суттєві зміни, встановлюються наукові, соціокультурні зв'язки 3 відомими вченими країни та педагогами-практиками (Володимирецький, Березнівський, Дубенський, Дубровицький, Сарненський райони, м. Рівне). Для прикладу, розглянемо систему національно-патріотичного виховання у школах Березнівського району Рівненської області. Характерною особливістю лекцій для вчителів (за участі Т.Д.Дем'янюк та інших науковців) $є$ практичний аналіз реалізації теоретичних положень у практиці виховання. Під час навчання педагогічних кадрів проводяться лекціїбесіди, лекції-диспути, лекції-консультації, лекції-візуалізації тощо.

Удосконаленню педагогічної майстерності вчителів та інших працівників установ освіти сприяють семінарські та практичні заняття 3 упровадженням активних форм роботи, зокрема: моделювання нетрадиційних виховних заходів на засадах народної педагогіки; ділові, рольові, особистісно-рольові ігри; дні творчості; соціальні ринги, на яких присутні представники богословських і філософських наук; панорами творчості «Світ моїх захоплень»; тренінгиспілкування; екскурсії в музеї; огляди, виставки-продажі літератури; творчі звіти, диспути, дискусії: «Практика виховної роботи національно-патріотичного змісту», «Учитель національної школи» та ін.; творчі портрети учителів початкових класів; учитель очима директора школи; виступи членів педагогічного колективу «Розповімо про свого колегу»; панорами методичних ідей, «круглі столи»: «Творчість, пошуки, проблеми, знахідки»; зустрічі з редколегіями газет; методичні фестивалі, кейсметоди вирішення педагогічних проблем; творчі звіти керівників дитячих гуртків; аукціони колективних творчих справ; педагогічні світлиці та ін.

Таким чином, в організації науково-методичної роботи надається перевага проблемнодискусійним формам та методам поширення педагогічних і методичних знань, які дають можливість створити сприятливі умови для розвитку ініціативи, творчості, самовдосконалення учасників всіх форм освіти і підготовки їх до практичної педагогічної діяльності.

Поширеною нетрадиційною формою роботи 3 молодими педагогічними кадрами $\epsilon$ створені за ідеями Т. Д. Дем'янюк клуби «Творчий педагог», «Креативність», «Досконалість» та ін., основне завдання яких - поглибити теоретичні знання педагогів-початківців; допомогти оволодіти практичними вміннями та навичками застосовувати їх на практиці; навчитися вести діалоги, дискусії, диспути; проводити нестандартні уроки та інноваційні позакласні заходи. На засіданнях клубів вчителі аналізують педагогічні ситуації, проводять конкурси, аукціони педагогічних ідей, апробують різновиди форм національно-патріотичного виховання учнів, засобами народознавства.

Висновки. Отже, здійснений аналіз ідей Т. Д. Дем'янюк дає змогу стверджувати, що вчена здійснила наукове обгрунтування використання педагогіки народознавства в організації національно-патріотичного виховання молодших школярів як «напряму в науці і шкільній практиці, що сприяє засвоєнню учнями культурно-історичних надбань українського народу, виховання гідних його спадкоємців і послідовників». Т. Д. Дем’янюк довела, що педагогіка народознавства «розглядає освіту і виховання як безперервні історичні процеси досягнень народу і синтезує здобутки його власної педагогіки та досягнення сучасних психологопедагогічних наук про особистість, людину, націю» [14]. Саме педагогіка народознавства, на іiі переконання, поєднує родинне, шкільне виховання в єдину цілісну систему, передбачає гармонійний розвиток особистості з глибокою національною самосвідомістю, формування активного борця за народні ідеали, громадянина, патріота. 
Багатий педагогічний досвід народу, його культура, історія, звичаї, традиції, обряди, мистецтво, народні символи, народна творчість - це ті засоби педагогіки народознавства, за допомогою яких можна виховати гідного представника свого народу, нації. Педагогіка народознавства має чітку систему високоефективних ідей, понять, принципів, доступних i емоційно насичених форм роботи з дітьми будь-якого віку. За умов творчого використання ідеї Т. Д. Дем'янюк, за умов врахування неодмінної умови: «форми народознавчої роботи, як і методи, повинні відповідати меті, цільовим установкам, змістові основного виховного задуму, відзначатися доступністю, привабливістю, оригінальністю» [9], використання педагогіки народознавства у національно-патріотичному вихованні молодших школярів стане дійсно ефективним і сприятиме створенню національної системи виховання на засадах української народної педагогічної спадщини.

\section{ЛIТЕРАТУРА}

1. Бех І. Виховання особистості. Кн. 1. Київ: Либідь. 2003. 280 с.

2. Дем'янюк Т., Кацинська Л. та Байрамова М. Використання народної педагогічної деонтології у створенні національної системи виховання. Рівне: ІПКПК. 1996. 91 с.

3. Дем'янюк Т., Дуляницька С., Лисенко О., Сакова Н. та Шидловька С. Виховання гуманістично спрямованої особистості. Рівне: Волинські обереги. 2011. 362 с.

4. Дем'янюк Т. Виховання духовності учнів загальноосвітньої школи засобами народознавства. В: Матеріали наук.-прак. конф. Рівне: ІПКПК. 1992. с. 16-18.

5. Дем'янюк Т. та Кацинська Л. Відзначення календарно-обрядових свят в сучасній школі. Осінній цикл. Ч. 4. Рівне: ІПКПК. 1996. 47 с.

6. Дем'янюк Т. Відроджуємо народні традиції. Літній цикл календарно-обрядових свят. Ч. 3. Рівне: РДПІ. 1996. $61 \mathrm{c.}$

7. Дем'янюк Т. Діяльність тимчасового науково-дослідного колективу педагогів Рівненщини. Нова педагогічна думка. 1. 2005. сс.7-13.

8. Дем'янюк Т. Експериментальні навчальні заклади Рівненщини. Рівне. 2003. 42 с.

9. Дем'янюк Т. Зміст та методика народознавчої роботи в сучасній школі: народознавча робота в позаурочний час. Київ: ІСДО, 1996. 108 с.+ 4 арк. вкл.

10. Дем'янюк Т., Лашта В., Мельничук Л. та ін. Інноваційні технології методичної роботи 3 педагогічними кадрами в умовах району. Рівне: Волинські обереги. 2005. 251 с. Бібліогр.: с. 247-248.

11. Дем'янюк Т., Вознюк Г. та Сухолейстер Г. Інноваційні технології трудового виховання учнів. КиївРівне: Волинські обереги. 2008. 175 с. Бібліогр.: с. 143.

12. Дем'янюк Т. Календарно-обрядові свята в школі. Зимовий цикл. Ч. 1. Рівне: РДПІ. 1996. 80 с.

13. Дем'янюк Т. Календарно-обрядові свята в школі. Весняний цикл. Ч. 2. Рівне: РДПІ. 1996. 80 с.

14. Дем'янюк Т. Методика виховання в сучасній школі. Київ. 2000. 286 с.

15. Стельмахович М. Українська родинна педагогіка. Київ: ІСДО. 1996. 300 с.

16. Сухомлинська О. Духовно-моральне виховання дітей та молоді: загальні тенденції й індивідуальний пошук. Київ: Всеукраїнський фонд - Добро. 2006. 350 с.

17. Сухомлинський В. Вибрані твори: в 5-ти т. Т. 5. Київ: Радянська школа. 1997. 200 с.

18. Ушинський К. Про народність у громадському вихованні. Вибрані педагогічні твори. Т.1. Київ: Радянська школа. 1983. 341 с.

19. Чорна К. та Ганнусенко О. Виховання моральності як основи духовного світу школярів в умовах розбудови української держави. Цінності християнської культури як фактор морально-етичного формування особистості. Київ. 2002. 129 с. 